\title{
ANALYSES OF TWO ICE CORES DRILLED AT THE ICE-SHEET MARGIN IN WEST GREENLAND
}

\author{
by
}

\author{
H.B. Clausen
}

(Department of Glaciology, Geophysical Institute, University of Copenhagen, Haraldsgade 6, DK - 2200 Copenhagen N, Denmark)

and

B. Stauffer

(Universität Bern, Physikalisches Institut, $\mathrm{CH}-3012$ Bern, Sidlerstraße 5, Switzerland)

\section{ABSTRACT}

In 1978 two ice cores were drilled to depths of 46 and $92 \mathrm{~m}$ respectively at Camp 3 , at the west margin of the Greenland ice sheet. Both core drillings reached bedrock. In addition, surface samples were collected in the marginal area along an estimated flow line.

The $\delta^{18} \mathrm{O}$ profiles of the two ice cores and of the surface samples show similar features. All three $\delta^{18} \mathrm{O}$ records reveal the characteristic shift (of 5-6 per mil for the Pleistocene-Holocene transition 11000 years ago) observed in Greenland deep ice cores from Camp Century and Dye 3 .

The $\delta^{18} \mathrm{O}$ results, as well as the measured temperature profiles in the bore holes, are used to provide more insight into the rheology of the ice sheet. The analyses of marginal ice samples is an important supplement to deep ice-core analyses.

\section{INTRODUCTION}

An ice sheet is an archive of precipitation from the past. In the central part of the polar ice sheets, the deposited snow is covered by subsequent snow layers and compacted into ice. The ice becomes more deeply buried as it moves towards the edge of the ice sheet, where it melts or calves, in the form of icebergs, into the ocean. According to flow models, the oldest ice (which originates from the ice divide) reaches the surface at the margin. Farther inland, younger ice (which originates from locations between the ice divide and the coast) will be found at the surface. The youngest ice will be at the equilibrium line (which separates the ablation area from the accumulation area). Surface samples taken along a flow line in the ablation area are therefore expected to show characteristics similar to those of an ice core from the interior of the ice sheet. Stable-isotope investigations on surface-ice samples from marginal zones in Greenland have confirmed this expectation (Raynaud 1977, Reeh and others 1987).

Ice cores to bedrock in the ablation area are expected to show the same record as surface samples along the flow line between bore hole and ice margin. We have drilled two ice cores to bedrock along an estimated flow line in the ablation area at Camp $3\left(69.7^{\circ} \mathrm{N}, 50.1^{\circ} \mathrm{W}\right)$ on the EGIG track in West Greenland (Fig.1). In this region the flow line, which starts at Crête (a possible location for a new deep drilling), reaches the ice margin. Results from the two ice cores are compared with results from surface samples collected along the estimated flow line between the bore holes and the ice margin.

\section{FIELD WORK}

Field work was done in the summers of 1977 and 1978. In 1977 about 20 ice cores, each to a depth of $1 \mathrm{~m}$,

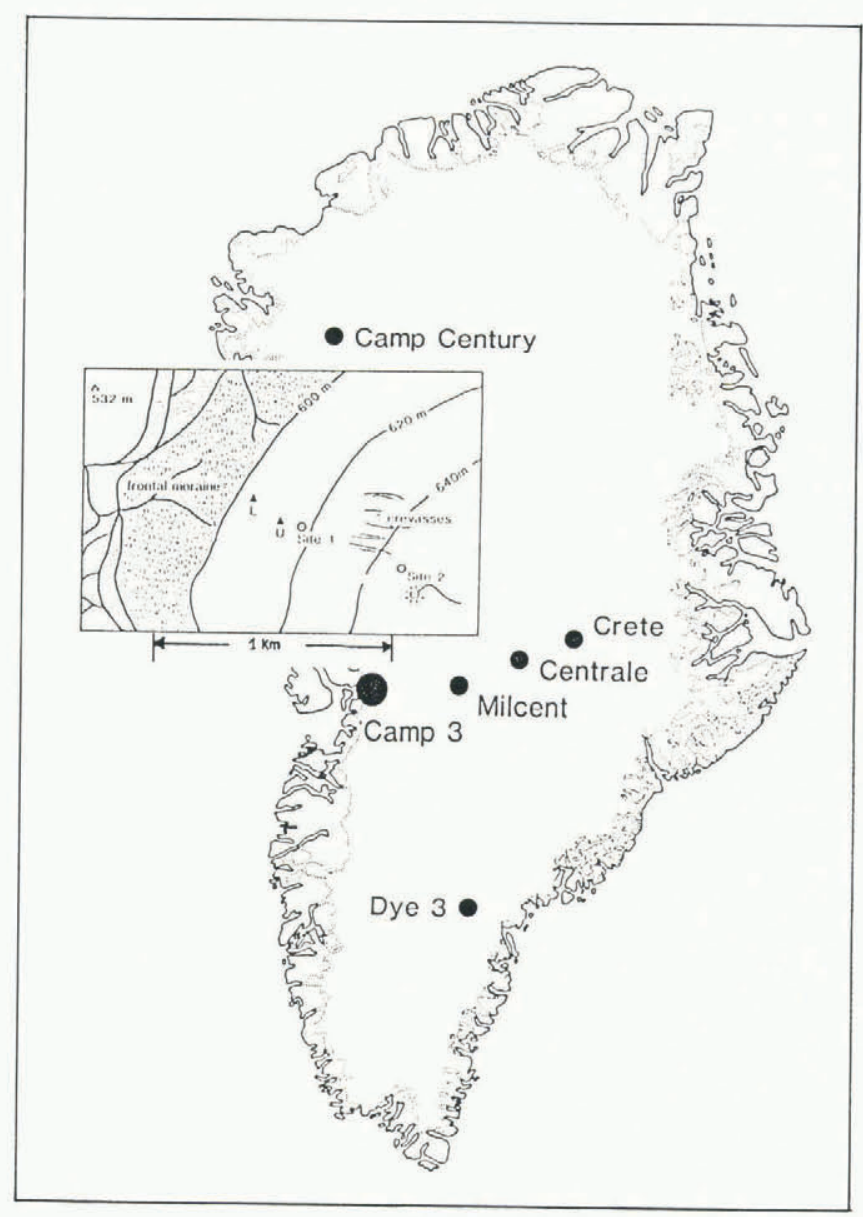

Fig.1. Map of Greenland, with the locations of Camp 3, Milcent, Station Centrale, Crête, Camp Century and Dye 3. The enlarged map of the Camp 3 region shows the position of the drill sites, "Upper" (U) and "Lower" (L) poles.

were recovered. The drilling sites were distributed along an estimated flow line from the edge of the moraine to about $400 \mathrm{~m}$ farther inland. The samples for stable-isotope measurements were prepared in the field.

In 1978 two ice cores to a depth of $46 \mathrm{~m}$ (drill site I) and to $92 \mathrm{~m}$ (drill site II) were drilled with an electromechanical auger developed and constructed at the University of Bern. The ice-core diameter is $7.5 \mathrm{~cm}$. 
Continuous cores were recovered, but they broke into disks a few centimeters thick. Drill site I was located $300 \mathrm{~m}$ inland from the edge of the moraine. Several small stones and some "pockets" of dirt were observed in the lower part of the ice core. At $46 \mathrm{~m}$ depth, drilling stopped due to a large boulder or to bedrock.

Drill site II was located $410 \mathrm{~m}$ farther inland. At $91 \mathrm{~m}$ depth the ice core became wet and all the ice chips in the core barrel were washed out. We assume that this was due to flowing water. The last meter of the ice core contained very few visible dirt particles. We stopped drilling, because we did not want to incur the risk of losing the drill.

The recovered ice cores were packed in plastic tubes, stored in freezers at a temperature below $-10^{\circ} \mathrm{C}$ and transported frozen to the laboratories in Copenhagen and Bern for stable-isotope $\left(\delta^{18} \mathrm{O}\right)$ studies.

Temperature profiles were measured in the bore holes (Stauffer and Oeschger 1979). The temperature decreased from the melting point at the surface to about $-5^{\circ} \mathrm{C}$ at $6 \mathrm{~m}$ depth. Below this depth, the temperature increased and again reached the melting point at $30 \mathrm{~m}$ depth. The ablation and the horizontal velocity were measured at two selected locations. The thickness of the ice sheet was measured with a $60 \mathrm{MHz}$ radar system from the Electromagnetic Institute at the Technical University of Denmark (TUD).

\section{RESULTS
1. $\quad \mathbf{6}^{18} \mathrm{O}$}

The $\delta^{18} \mathrm{O}$ values from the ice cores are shown on a depth scale in Figures 2 and 3 . There are detailed $\delta^{18} \mathrm{O}$ records, based on $10 \mathrm{~cm}$ samples, for the bottom part of the two cores, 29 and $24 \mathrm{~m}$ respectively. As these records do not provide any extra information, they are not shown here.

\section{Drill site I}

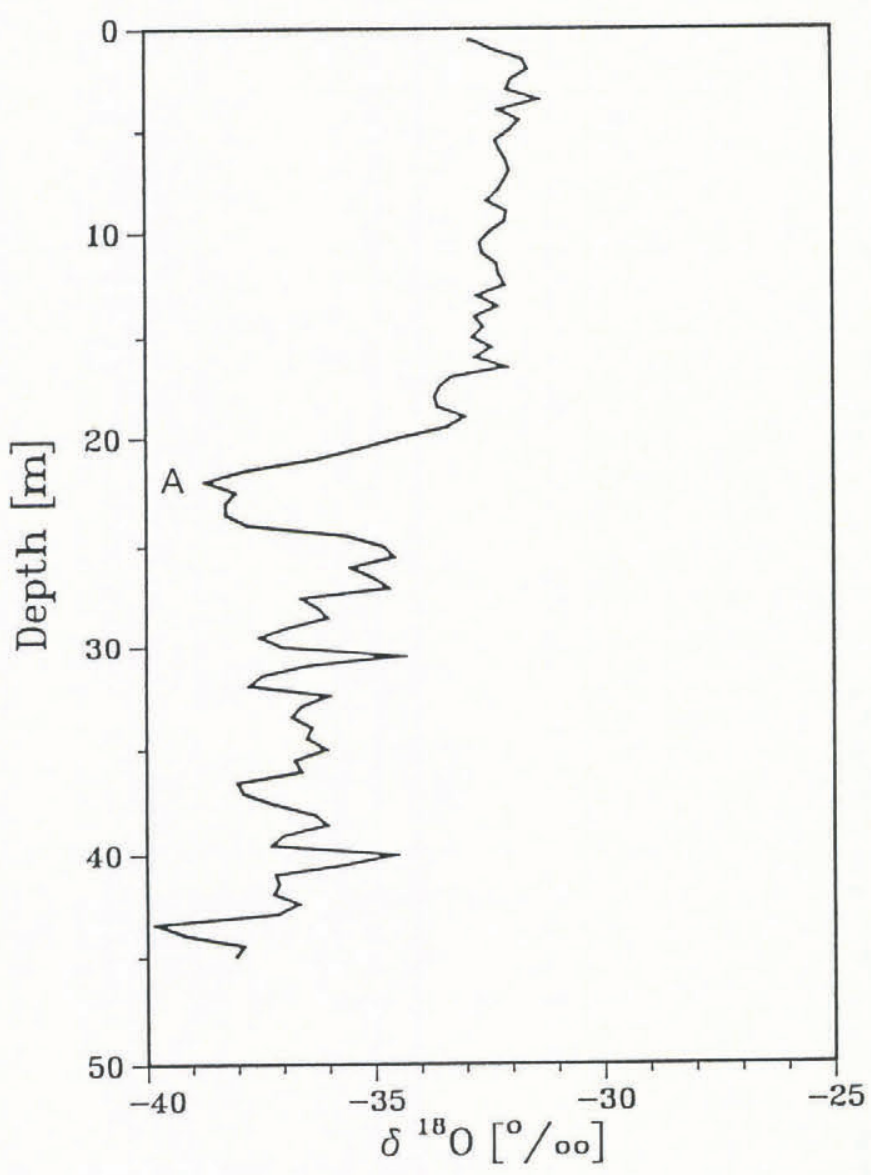

Fig.2. The continuous $\delta^{18} \mathrm{O}$ record of the ice core from drill site I, on a vertical depth scale. The $\delta^{18} \mathrm{O}$ sample length is $50 \mathrm{~cm}$. The minimum "A", at the depth of $22 \mathrm{~m}$, corresponds to the Younger Dryas, just before the Pleistocene-Holocene shift 11000 years ago. The record reveals a $\delta^{18} \mathrm{O}$ shift of $6 \%$ in the depth interval

$18-222 m_{0} 0305500004109$ Published online by Cambridge University Press
The surface $\delta^{18} \mathrm{O}$ profile in Figure 4 is shown versus distance from the moraine. This profile comprises 44 points spaced $5-10 \mathrm{~m}$ apart, starting at the stagnant moraine and ending $100 \mathrm{~m}$ above drill site I. Each point represents the mean of $10 \mathrm{~cm}$ samples from a $1 \mathrm{~m}$ hand-augered ice core.

\section{Ablation, horizontal velocity and surface slope}

Two poles were erected in 1977 on the ice surface, 150 and $300 \mathrm{~m}$ from the moraine. Based on measurements made in 1977 and 1978, we estimate the annual ablation and horizontal velocity shown in Table I.

\section{TABLE I. GLACIOLOGICAL CHARACTERISTICS}

Ablation Horizontal velocity $\mathrm{m}$ of ice/year $\mathrm{m} /$ year

"Lower pole"

"Upper pole"

2.4

2.6

10

Range

Measured mean surface slope Degree

Moraine - drill site I

Drill site I - drill site II

Drill site 11 - Camp 3bis

\section{Radar-sounding}

In 1971, a TUD airborne-radar survey $(60 \mathrm{MHz})$, close to the EGIG track, showed that the ice thickness increases some $600 \mathrm{~m}$ in the distance interval $4-5 \mathrm{~km}$ from the edge

\section{Drill site II}

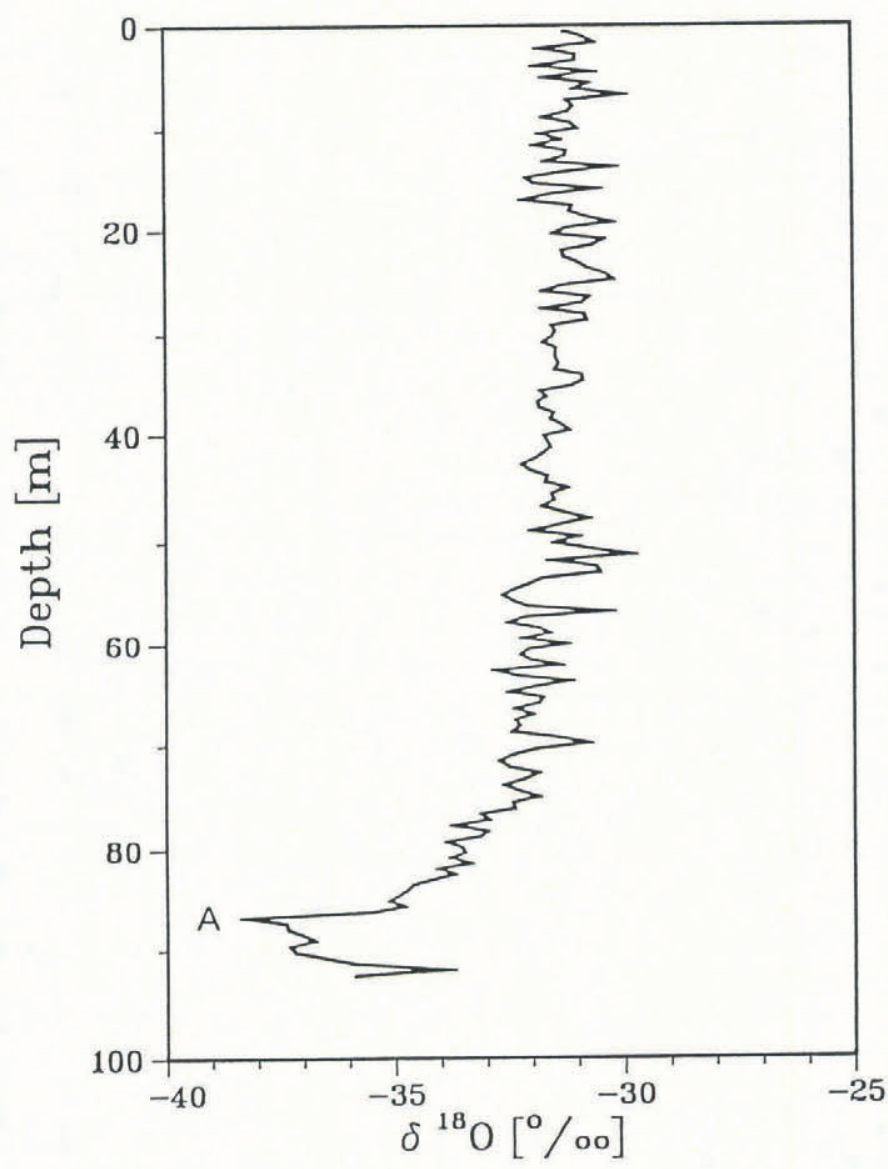

Fig.3. The continuous $\delta^{18} \mathrm{O}$ record of the ice core from drill site II on a vertical depth scale. The $\delta^{18} \mathrm{O}$ sample length is $55 \mathrm{~cm}$. The minimum " $\mathrm{A}$ " is found at $86 \mathrm{~m}$ and the $6 \% 0 \delta^{18} \mathrm{O}$ shift is found in the depth interval $75-86 \mathrm{~m}$. 
Camp3, Surface profile

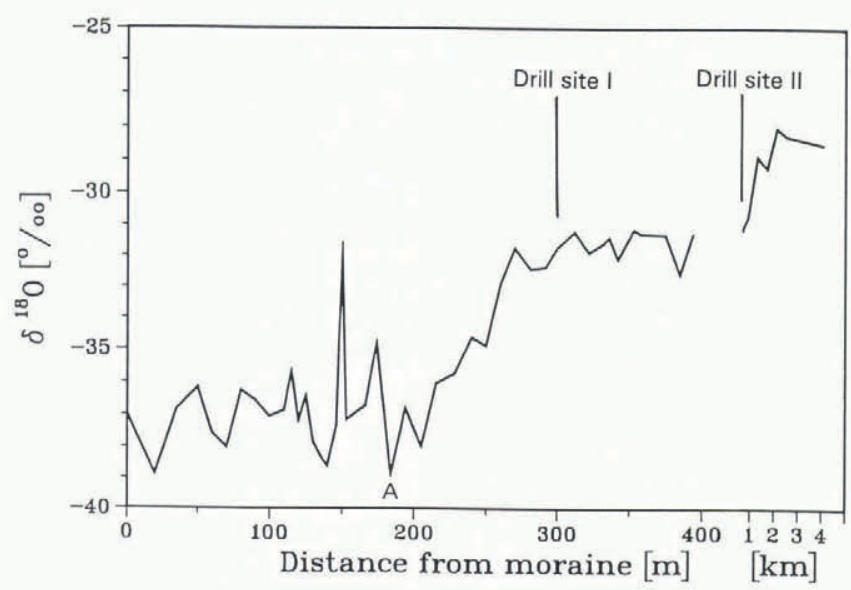

Fig.4. The $\delta^{18} \mathrm{O}$ record based on surface samples collected from $1 \mathrm{~m}$ ice cores spaced $5-10 \mathrm{~m}$ apart on an estimated flow line through drill sites I and II. The horizontal scale represents distance from the stagnant main moraine. Note the different units on this scale. The minimum " $\mathrm{A}$ " is found $184 \mathrm{~m}$ from the moraine, and the $6 \% \delta^{18} \mathrm{O}$ shift spans the distance $184-270 \mathrm{~m}$.

(Gudmandsen 1973). As we hoped to be able to measure the ice thickness at the terminus itself, the $60 \mathrm{MHz}$-radar was hauled on the surface from drill site I to the former EGIG site, Camp 3bis, $4 \mathrm{~km}$ up-stream. Single-shot measurements were made for every $200 \mathrm{~m}$ between the moraine and a point $2.6 \mathrm{~km}$ from the moraine, and again at the site, $4 \mathrm{~km}$ from the moraine. Two depth measurements, recorded on an instant film, were performed at each site, with the antenna oriented along and across the expected flow line. The results are ambiguous, except for Camp 3 bis, where a clear bottom signal shows an ice depth of $170 \mathrm{~m}$. The bedrock at this site is $540 \mathrm{~m}$ a.s.l. The results from the other sites (the bottom $2.6 \mathrm{~km}$ of the profile) are difficult to interpret, but indicate depths in the range 100-200 m. The difficulty is probably due to the high content of free water $(3 \%)$ in the ice from the lower part, compared to the low content $(0 \%)$ at Camp 3 bis (Stauffer and Oeschger 1979).

\section{Analyses of gases extracted from ice samples}

A few gas analyses have been performed on samples from the drill site I ice core. The results are given in Table II and are compared with a mean value of nine ice samples from the thermally drilled Crête ice core (Stauffer 1981). The air has been extracted by a melt-extraction method, which leads to excessive $\mathrm{CO}_{2}$ values, due to chemical reaction with impurities in the melt water. Therefore no $\mathrm{CO}_{2}$ results are presented here.

\section{DISCUSSION OF RESULTS}

The surface profile and the lower part of both ice cores show more negative $\delta^{18} \mathrm{O}$ values than any surface values found in central Greenland today. All three records show a characteristic shift of between 5 and $6 \%$ in $8^{18} \mathrm{O}$ values. This shift is similar to that observed in Greenland deep ice cores for the Pleistocene-Holocene transition (Dansgaard and others 1982). Therefore we conclude that this shift in the three records represents ice from the same period, i.e. the final transition from the last glaciation to the Holocene, dated at 10750 years B.P. (Hammer and others 1986). The minimum, marked " $A$ " in the three records, is thus part of the Younger Dryas. The feature represented by the $6 \%$ change in all three records is the only isochrone we place with confidence on all the records, even though it looks as if all the records show the termination of the warmer Allerød period, and the records from drill site $I$ and the surface show the entire Allerød period, which occurred before the Younger Dryas period.

In all three records the $\delta^{18} \mathrm{O}$ values of the oldest Holocene ice are $-32 \%$, corresponding at present to a mean annual temperature of $-26.3^{\circ} \mathrm{C}$ at the site of formation (Dansgaard 1961). This value suggests that the ice originates from a location between Station Centrale and Milcent some $350 \mathrm{~km}$ from the terminus of the ice. In addition, flow characteristics lead us to expect that the ice at Camp 3 originates from a region between Station Centrale and Milcent (Reeh 1984). The relatively short travel distance for the ice at Camp 3 is not surprising, as Camp 3 is located between the ice streams to Equip Sermia at the north and Jakobshavn ice stream to the south, and is thus in a region where divergent flow can be expected.

Data for the two ice cores are shown in Table III.

The $150 \mathrm{~m}$ of the surface profile closest to the moraine consist of "black ice", i.e. clear ice with very few air bubbles and inclusions of fine dust particles, concentrated in "pockets". The low $\delta^{18} \mathrm{O}$ values of this ice $(-37 \%)$ are also found in the bottom part of the ice from drill site I, whereas it is missing in the ice core from drill site II. The

TABLE II. AIR CONTENT AND AIR COMPOSITION IN ICE SAMPLES FROM CAMP 3 AND CRÊTE

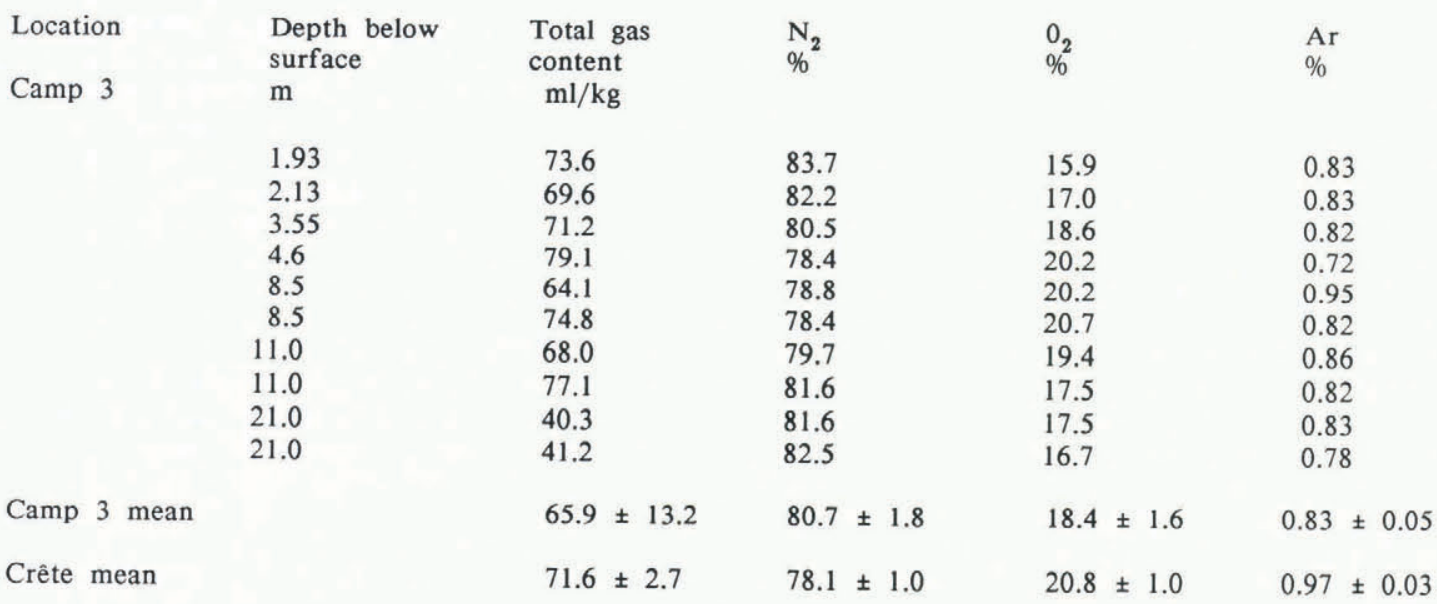


TABLE III. ICE CORE CHARACTERISTICS

Ice cores from

Distance from the moraine

Length of ice core

Length of $\delta^{18} \mathrm{O}$ samples in Figures 1 and 2

Depth of Pleistocene-Holocene transition

$\delta^{18} \mathrm{O}$ value of Younger Dryas

$\delta^{18} \mathrm{O}$ value at the surface

thickness of this "black ice" (which represents ice older than $11 \mathrm{ka})$ can be calculated, assuming that equilibrium and no divergent flow exist on a plain bedrock in the terminus region which has been investigated here. Bauer (1968) reports that the end moraine has been stagnant since at least 1912. For this region Renaud (1969) gives a rate of ablation of $2.10 \mathrm{~m}$ of ice per year and Bauer (1968) gives a horizontal velocity (determined during the years 1948-59) of $18 \mathrm{~m}$ per year. Our measurements, which are based on the single year 1977-78, are not inconsistent with these values. The assumption of no divergent flow makes the point A (a Younger Dryas isochrone), in Figures 2, 3 and 4, part of the same flow line. In Figure 5 the flow line is shown as the regression line, based on the three points A. Using a simple continuity calculation and assuming that our measured horizontal velocity of $15 \mathrm{~m}$ per year and the annual ablation of $2.5 \mathrm{~m}$ per year are typical for the region under investigation, we recorded a $30 \mathrm{~m}$ thick layer of "black" ice at the bottom in the marginal zone at Camp 3 (see Fig.5).

The results of the total gas content, and especially of the gas composition, for Camp 3 deviate from the mean value of samples from Crête. The lower gas content and the depletion of more soluble air components (like $\mathrm{O}_{2}$ and $\mathrm{Ar}$ ) can be explained by assuming that internally produced melt water has left the ice after achieving equilibrium with the

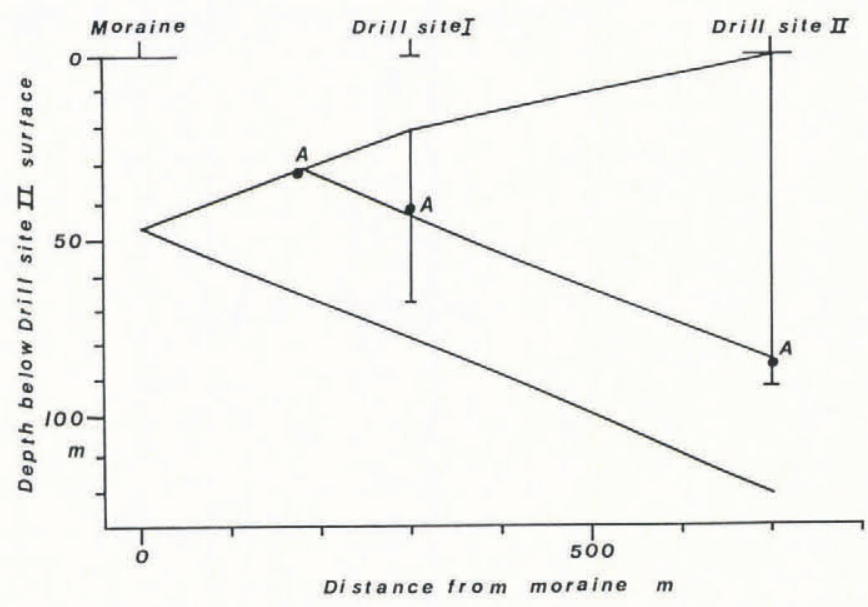

Fig.5. A sketch of the marginal zone at Camp 3, with the locations of the two drill sites. The vertical scale represents distance in meters below the surface at drill site II. The horizontal scale represents distance in meters from the stagnant main moraine. The surface slope is plotted from measured values and a plain bottom is assumed in this region. "A" indicates the position of the Younger Dryas minimum in the three ${ }^{18} \mathrm{O}$ records. The regression line through the points "A" $((185,-32)(300,-43)$ and $(710,-86))$ determines a flow line and a $30 \mathrm{~m}$ thick layer of "black ice" at the bottom of the ice (see text).
Drill site I

Drill site II

$300 \mathrm{~m}$

$710 \mathrm{~m}$

$46 \mathrm{~m}$

$92 \mathrm{~m}$

$0.50 \mathrm{~m}$

$0.55 \mathrm{~m}$

$22 \mathrm{~m}$

$86 \mathrm{~m}$

$-38.5 \%$

$-38.5 \%$

$-31.8 \%$

$-31.2 \%$ air in the bubbles at the corresponding pressure (Stauffer 1981). If we exclude the values from $21 \mathrm{~m}$ depth, the mean total gas content for Camp 3 does not deviate significantly from the Crête value; however, a significant depletion of the more soluble components exists in Camp 3, relative to Crête, and the large scatter in total gas content could be due to non-uniform wash-out processes.

\section{CONCLUSIONS}

The three $\delta^{18} \mathrm{O}$ profiles clearly exhibit the PleistoceneHolocene transition 11000 years ago. As in other Greenland deep ice cores, this transition is represented by a $\delta^{18} \mathrm{O}$ shift of 6 per mil (from -38 to $-32 \%$ ) in all three records.

The ice at the margin is temperate but covered by a layer of cold ice, which prevents the surface melt water from percolating the temperate ice. This protective layer explains why the $6^{18} \mathrm{O}$ records give no indication of any fractionation due to melt-water percolation (Arnason 1969). The preservation of $\delta^{18} \mathrm{O}$ oscillations in this temperate ice is understandable too when we consider the minor loss of mass in the form of melt water (of the order of only $1 \%$ ), as calculated from the measurements of the gas content and composition (Stauffer 1981).

In the marginal zones it is relatively easy to recover large ice samples which originate from the last glaciation. However, the dating of the ice is less accurate than in deep ice cores from the central part of the ice sheet. The scientific value of the ice at Camp 3 is limited, because this ice is temperate. We know that the gas content and composition are affected substantially by the influence of melt water and we conclude that the concentration of soluble impurities is affected as well.

There is a strong indication from our results that the stratigraphy is still preserved in the marginal zone. The transition from Pleistocene to Holocene ice was found, both at the surface and in the two ice cores, at the depth predicted by a simple flow model. Therefore the "Younger Dryas isochrone" seems to form a continuous plane in the ice. There is no indication of large-scale folding or of discontinuities.

Investigations in the ablation area of an ice sheet can never replace deep drilling in the interior of an ice sheet. Deep-drilling operations should, however, be supplemented by investigations in the corresponding marginal areas. Investigations in the future should include core drillings farther inland in the ablation zone. If the ice temperature farther inland is below the freezing point, results from measurements of the gas composition and the concentration of chemical impurities can be compared with the results from deep cores.

\section{ACKNOWLEDGEMENTS}

We thank the Swiss National Science Foundation and the Commission for Scientific Research in Greenland for financial support, and the Royal Greenland Trade Department (KGH) in Jakobshavn for logistic support. 


\section{REFERENCES}

Arnason B 1969 The exchange of hydrogen isotopes between ice and water in temperate glaciers. Earth and Planetary Science Letters 6(6): 423-430

Bauer A 1968 Mouvement et variation d'altitude de la zone d'ablation ouest. Meddelelser om Grenland 174(1)

Dansgaard W 1961 The isotopic composition of natural waters with special reference to the Greenland ice cap. Meddelelser om Grønland 165(2)

Dansgaard W and 6 others 1982 A new Greenland deep ice core. Science 218(4579): 1273-1277

Gudmandsen P 1973 Radioglacialogy soundings at proposed drill sites. Lyngby, Technical University of Denmark. Laboratory of Electromagnetic Theory (D185)

Hammer C U, Clausen H B, Tauber H 1986 Ice-core dating of the Pleistocene/Holocene boundary applied to a calibration of the ${ }^{14} \mathrm{C}$ time scale. Radiocarbon $28(2 \mathrm{~A})$ : 284-291

Raynaud D 1977 Les inclusions gazeuses dans la glace de glacier. Grenoble, Centre National de la Recherche Scientifique, Laboratoire de Glaciologie (Publication 214)

Reeh N 1984 Reconstruction of the glacial ice covers of Greenland and the Canadian Arctic islands by three-dimensional, perfectly plastic ice-sheet modelling. Annals of Glaciology 5: 115-121

Reeh N, Thomsen H H, Clausen H B 1987 The Greenland ice-sheet margin - a mine of ice for paleo-environmental studies. Palaeogeography, Palaeoclimatology, Palaeoecology 58: $229-234$

Renaud A 1969 Études physiques et chimiques sur la glace de l'indlandsis du Groenland 1959. Meddelelser om Gronland 177(2)

Stauffer B 1981 Die Zusammensetzung der Luft in natürlichem Eis. Zeitschrift für Gletscherkunde und Glazialgeologie 17(1): 57-78

Stauffer B, Oeschger H 1979 Temperaturprofile in Bohrlöchern am Rande des grönländischen Inlandeises. Mitteilungen der Versuchsanstalt für Wasserbau, Hydrologie und Glaziologie an der Eidgenössischen Technischen Hochschule (Zürich) 41: 301-313 